\title{
The concept of 'Crisis' in the thought of Cornelius Castoriadis
}

Christos Memos

This is an Accepted Manuscript of a book chapter published by Routledge in The persistence of critical theory on January 2017, available online: http://www.routledge.com/The-Persistence-of-CriticalTheory/Ricci/p/book/9781412864282 
Christos Memos

Abertay University, Dundee

\section{The Concept of 'Crisis' in the Thought of Cornelius Castoriadis}

'The history of a text', according to Karel Kosik, 'is the history of its interpretations' and 'every interpretation of a text is always also its evaluation'. (Kosik 1976: 94, 95) This in turn, implies that every interpretation-evaluation accentuates distinct features of the text or the scholar under examination, thus disclosing and accrediting discrete meanings to them. More significantly, this process of understanding an author and comprehending her texts by concentrating on concrete aspects of her work has considerable theoretical and political implications. No doubt, the above could be applied with equal force to the texts and the whole body of Cornelius Castoriadis's work. The growing recognition of his thought and the attractiveness of his writings are almost exclusively associated and in many cases totally identified with some of his later philosophical writings. This part of his theorising was assigned a merit that tends not only to overshadow the totality of his theoretical production. It has also been taken the form of a closed system, which through a process of ruthless canonisation has established a 'paradigm' of what constitutes the essence and most fundamental elements, the crux of Castoriadis's thought. By focusing entirely upon some of his later philosophical texts, most of Castoriadis's commentators have consciously or unconsciously produced and re-produced a particular interpretation of his thought, which turns out to be misleading and obscure. This procedure was backed up by an ongoing evocation and application of a selective philosophical terminology. By omitting almost entirely Castoriadis's political and social writings, Castoriadis's thought has been classified on the basis of a firm and peculiar vocabulary whose familiarity and constant usage constitutes an absolute pre-supposition for a first encounter or a more systematic engagement with Castoriadis. The construction of Castoriadis's 'jargon', including concepts such as 'imagination', 'imaginary significations', 'chaos', 'creation', 'monad', 'psyche', 'magma', 'ensemblistic-identitary logic', 'legein and teukhein', 
'Anlehnung', reinforces an one-sided interpretation of his thought that abstracts from real historical and social factors.

This kind of philosophical analysis omits almost entirely the social and political content of his writings and channels his thought into de-politicisation, thus establishing a preconceived norm, which could be easily accommodated and led into a conformist direction. It departs from the complex and multifaceted character of his analysis and conceals Castoriadis's political commitments. Such approaches have moved away from Castoriadis's radicalism and tend to neglect the anti-capitalist elements of his thought or to treat them as obsolete and by extension to nullify Castoriadis's 'political, praxical, revolutionary perspective'. (Castoriadis 1993a: 276) In contrast to these commentators, Castoriadis was adamant that he was first and foremost a political thinker. I his own words: 'I have never considered myself to be only a philosopher but always someone who wants to do philosophy and politics at the same time...This persistence, this adherence to the political project, distinguishes me considerably from everything that is being written today'. (Castoriadis 1995: 31) Castoriadis's project of social emancipation amounted not only to critical understanding of the existing capitalist social relations, but, most importantly, to a constant struggle of changing and radically transforming them. ${ }^{1}$ Viewed this way, it can be said that Castoriadis`s later philosophical writings should be read and construed through the lens of his political and social writings and not vice versa.

Spelling out the implications of this perspective, then, this interpretation challenges other prevalent strands of commentary on Castoriadis which comprehend his thought by putting an exclusive accent on a specific part of his later philosophical writings, thus creating a self-sufficient space of meaning embellished with a Castoriadian jargon. In a like manner, it rejects those accounts which perceive Castoriadis's critique of Marx and Marxism as being part of the post-modernist tradition that rebuffs grand narratives and advocates western forms of liberal and representative democracy. Instead and in accordance with Castoriadis`own commitment, his work is placed in a critical dialogue with Marx and Critical Theory. ${ }^{2}$ In this sense, the argument of this chapter is that the concept of 'crisis' constitutes a core problematic of Castoriadis's theorizing. 
Castoriadis`s theory of crisis reflects his intellectual development and connects the several stages of his evolution. It does not deny Castoriadis`s intellectual development, but it portrays the continuities and discontinuities, turns and new beginnings, ruptures and contradictions of his thought. The concept of crisis remained a focal point in the thinking of Castoriadis through his critical confrontation with both the crisis of Marxism and traditional Leftist theory and practice and the crisis of modern capitalist societies. This chapter focuses on Castoriadis`s critical and topical engagement with the crisis of the latter and stresses its relevance for contemporary critical theory. First, it examines Castoriadis`s correlation of the crisis of modern societies with the concept of reification and the impact of class struggles. Crisis is discussed here as being inherent to the contradictory and antagonistic constitution of the capitalist social relations and Castoriadis is situated in a critical dialogue with Lukács and Adorno. Second, the chapter goes on to critically explore Castoriadis`s subsequent view of the crisis as a phenomenon ensuing from the conflict between the social imaginary significations of 'autonomy' and the unlimited expansion of 'rational mastery', which has led to the eclipse of the project of autonomy. Finally, it engages with Castoriadis`s argument that modern societies are moving from a state of permanent crisis to a situation of decline and decomposition, manifested in the rising tide of insignificancy and new forms of barbarism.

\section{Castoriadis, Lukács, Adorno: Crisis and Reification as a Dynamic Concept}

The theme of 'crisis' is central to Castoriadis`s writing and runs throughout his work from his very early years in France. The importance of his analysis lies in the importance that the concept of reification has in his exposition of his theory of crisis. He conceived of the recurring crises of modernity as a phenomenon inherent in capitalist social relations, which is correlated with the process of reification and the people`s militant opposition to their ongoing and pervasive thingification. Against the background of the Second World War tragic experience, as well as the post-war socioeconomic developments in both USA and USSR, Castoriadis was led to question the traditional Marxist approaches on the issue of crisis. This was the corollary of his critical attitude towards Marx and his gradual rupture with classical Marxism, although during his early period in France, which runs roughly from 1945 until the late 1960s, he remains within 
Marx`s and critical Marxism`s theoretical framework. Castoriadis views the category of reification as the 'most important aspect of Marx`s doctrine' (Castoriadis 1993b: 54), which Lukács had elaborated further in his History and Class Consciousness. One of Castoriadis`s basic assumptions was his point that both Western and East European regimes are marked by common tendencies, which encompassed the merging of state and economy, the concentration of capital and the bureaucratization of societies. On an international scale, the bureaucracy emerged as a new social stratum and substituted the traditional bourgeoisie. In this line of thought, he opined that all these global developments and trends were likely to lead the two systems - the American and the Russian - to a convergence. Within this world context, society is not any more ruled by the traditional function of capital or the abstract forces of the market, but it is dominated by a 'hierarchical bureaucratic structure'. (Castoriadis 1993b: 31) On this criterion, Castoriadis challenged the classical Marxists views by arguing that the fundamental contradiction inherent in capitalist society shifted from the division between capital and labour to the split and conflict between direction and execution.

Castoriadis`s direct engagement with what he considered to be as the Marxist problematic with regard to the concept of reification led him to criticize Marx`s usage of the term. For Castoriadis, Marx placed too much emphasis on the study and discovery of the scientific economic laws that govern capitalist societies at the expense of the action of social classes. An important aspect of Castoriadis`s critique concerns Marx's theory of fetishism, which is viewed as an 'abstraction that corresponds [...] with only half of reality, and as such it is ultimately false'. (Castoriadis, 2005: 16) Following Castoriadis`s view, reification cannot be complete and the workers in capitalism are by no means fully reified and entirely alienated. In addition to being a touchstone for his analysis, Castoriadis further elaborated the notion of reification by perceiving it as a dynamic concept, in a manner that resembles Adorno`s corresponding treatment of the notion under discussion. Castoriadis deploys his conception of the relationship between reification and crisis by focusing on the appearance of crisis in post-war modern societies. Firstly, the crisis is displayed in the collective practical activity of the people who struggle against their reduction to objectified commodities. 
Revolts, rallies, protests of any kind, strikes, sit-ins and everyday militancy and resistance challenge the ubiquitous dominance of reification and the mechanisms which produce and reproduce it. The Hungarian uprising of 1956 and the French May of 1968 constitute key examples of people`s struggle against reification. Secondly, crisis is demonstrated as depoliticization, privatization, apathy, nonparticipation and unresponsiveness to social and political issues. Such instances of detachment can be seen as symptomatic expressions of an invisible fighting against the thingified reality or the depersonalisation and dehumanization of individuals in capitalist bureaucratic societies. Viewed this way, as Castoriadis noted, 'in both cases, beyond a certain point this conflict leads to the overt crisis of the established society'. (Castoriadis 1988a: 155-156) These two expressions of crisis run through the whole body of Castoriadis`s theorizing and indicate the underlying continuity between his early and later writings.

As far as the first approach is concerned, Castoriadis's theory of crisis grants a central role to the dynamic of class struggle and the working class organised protest as the factors which spark off the crises of the capitalist system. As he argues the capitalist crises are the 'by-product of struggle'. (Castoriadis 1993c: 115) Opposed to any deterministic and objective interpretations of crisis ensuing from the abstract and natural laws of capitalist economy, crisis is viewed by Castoriadis as a social category. Crises are inherent to capitalist social relations and occur due to a systemic fundamental contradiction. If for Lukács the 'structure of a crisis is seen to be no more than a heightening of the degree and intensity of the daily life of bourgeois society' (Lukács 1971: 101), for Castoriadis crises are founded on the intensified conflict between directors and executants in the sphere of work and production. Crisis as a social phenomenon, as a category of social contradiction, is inherent in the theory of reification, within the conditions of alienation experienced by workers in their everyday life under the capitalist organisation of social relations. In contrast to Lukács account, the notion of reification that informs Castoriadis`s theorising of crisis emphasises his view of crisis as non-static and non-rigid. It rather should be understood as a contradictory, fluid and dynamic concept that mirrors the conflicting and antagonistic relationship between directors and executants. 
According to Horkheimer, 'tension characterizes all the concepts of the critical way of thinking $[\ldots]$ the critical acceptance of the categories which rule social life contains simultaneously their condemnation'. (Horkheimer 1972: 208) Following this line of thought, Castoriadis does not view reification as a fixed concept or as a hypostatised moment. He develops a processual and dialectical understanding of the notion of reification, which is rooted unequivocally and explicitly in people`s life process and in workers`experience. For Lukács the advance of the capitalist organization of society is constantly proceeding at higher levels of development and 'the structure of reification progressively sinks more deeply, more fatefully and more definitely into the consciousness of man' (Lukács 1971: 93). Stating the point differently, Lukács argued that "the transformation of the commodity relation into a thing of "ghostly objectivity", is not limited to an entire commodification of human life, but most importantly 'it stamps its imprint upon the whole consciousness of man' (Lukács 1971: 100) and 'this rationalization of the world appears to be complete, it seems to penetrate the very depths of man`s physical and psychic nature'. (Lukács 1971: 101) In contradistinction to Lukács, the reflections on a dynamic analysis of reification, which Castoriadis delineates, grasp it as an ever incomplete, contradictory and unpredictable process, which is subjected to and definitely shaped by the complex and diverse struggles of the people. As Castoriadis argued,

Reification, the essential tendency of capitalism, can never be wholly realized. If it were, if the system were actually able to change individuals into things moved only by economic 'forces', it would collapse not in the long run, but immediately. The struggle of people against reification is, just as much as the tendency towards reification, the condition for the functioning of capitalism. A factory in which the workers were really and totally mere cogs in the machine, blindly executing the orders of management, would come to a stop in a quarter of an hour. (Castoriadis, 2005: 16)

For Castoriadis, reification, as a unity of two clashing movements that subsist in a continuous struggle, could never be completed. The workers in capitalism are by no means fully reduced to things. They are never being entirely reified and utterly alienated. Reification could be grasped only as a dynamic process, a constant struggle between reification and anti-reification, both elements always coexisting as antagonistic processes. 
The incomplete reification and the fact that the people in capitalism have been alienated go hand in hand with their struggle against this reification, against their reduction into objects. Yet this imperfect reification constitutes the driving force and at the same time indicates the fragility, the vulnerability and the ultimate contradiction of capitalism. Refusal, resistance and struggle against reification compose the 'remainder', what is left and contradicts the competence of the concept. It is the contradiction which, as Adorno put it breaking with Lukács`s 'wishful image of unbroken subjective immediacy' (Adorno 2003: 374), is 'nonidentity under the aspect of identity' (Adorno 2003: 5). It is the 'distant and different' (Adorno 2003: 191) that cannot be fully conceptualized or according to Horkheimer the 'chaotic...that which has not been included' (Adorno and Horkheimer 2011: 27). Reification then, for Adorno, is an 'epiphenomenon', which cannot be resulted from a 'subjectively errant consciousness, but objectively deduced' arises from what is responsible for the social and economic misery, that is, 'the conditions that condemn mankind to impotence and apathy and would yet be changeable by human action'. (Adorno 2003: 190) Rather, as Adorno emphatically stressed, Lukács`s analysis 'hypostatized the indirect as direct'. (Adorno 2003: 374) Whereas for Lukács reification appears as a closed category, in which the dynamic elements are degraded to a lower level of importance, for Adorno "every "is"...contains an..."is not"...every identity contains non-identity' (Adorno 1961: 40) — the 'unknown ...that cannot be calculated'. (Adorno 1967a: 66)

Lukács unfolds the theoretical premises of his positions by arguing that the unceasing commodification and rationalization of modern life penetrates both the individual and society as a whole. Reification is universalized to that extend that mechanization is embedded even into the worker`s soul. At the core of this position is the notion that the individual is being fragmented and this split in his existence results in the reified, mechanically objectified "performance" of the worker, wholly separated from his total human personality'. (Lukács 1971: 90) Capitalist production methods treat workers as mechanized entities and rationalized tools, who must function and perform in a fully instrumental manner. Viewed this way, Lukács asserts with regards to the phenomenon of alienation that 'only when man's nature is subjugated, deformed and crippled can we 
speak of an objective societal condition of alienation and, as an inexorable consequence, of all the subjective marks of an internal alienation'. (Lukács 1971: xxiv) Adorno in turn is concerned with showing that we cannot presuppose that there is not a non-reified human essence that becomes alienated by the external thoroughly mechanized and rationalized reality, and in which 'pure' subject is subjugated and dehumanised. There is not a motionless and authentic state of being that precedes reification and dehumanisation. As becomes clear, then, for Adorno:

the pat phrase about the "mechanization" of man is deceptive because it thinks of him as something static which, through an "influence" from outside, an adaption to conditions of production external to him, suffers certain deformations. But there is no substratum beneath such 'deformations', no ontic interior on which social mechanisms merely act externally: the deformation is not a sickness in men but in the society which begets its children with the 'hereditary taint' that biologism projects on to nature. (Adorno 2005: 229)

Akin to Adorno`s approach, Castoriadis makes sense of alienation, social heteronomy, as a social phenomenon. He takes issues with the "purely "psychological" view of alienation, the one which seeks the conditions of alienation solely in the structure of individuals', which he deems to be 'unilateral, abstract and, ultimately, false'. (Castoriadis, 2005: 385) Castoriadis attaches great importance to the social dimensions of the issue and hence he suggests that 'the conditions for alienation are to be found in the social world'. (Castoriadis, 2005: 108-9)

In Minima Moralia, however, in a manner that could be seen as rather mechanistic and quite controversial, Adorno applied Marx`s notion of the 'organic composition of capital' to individuals living in a capitalist society arguing that the 'organic composition of man is growing'. (Adorno 2005: 229) Extending Marx`s views, Adorno contended that the constantly changing rate between the constant and variable capital at the expense of the latter, is also reflected within individuals in an analogous fashion: 'That which determines subjects as means of production and not as living purposes, increases with the proportion of machines to variable capital'. (Adorno 2005: 229) As a critique of conservative investigations on the theme of the crisis of the individuals, Adorno 
succeeded in putting the accent on the objective social conditions which dominate, constitute and transform human beings in capitalism. By conceiving the notion of reification and the ongoing alienation of human beings as the outcome of a social process, he made an effort to investigate this phenomenon materialistically. Nonetheless, at least at this point, Adorno seems to absolutize the social character of reification and overlook the role of subjectivity, as the constitution of the subject appears as a reflection of the external conditions. Hence, as Marx would say, 'he does not grasp the significance of "revolutionary", of practical-critical activity', and the reified reality is not also conceived 'as human sensuous activity, practice' (Marx 1991: 28) that is to say, subjectively. The objection raised here to Adorno`s approach regarding the 'rising organic composition of man' (Adorno 2005: 231) concerns his split between subject and object, which reproduces a dualist conception of society. Despite his intentions to the contrary, capitalist society and human beings are perceived as separate spheres and it is regarded that the latter receive rather passively and internalize the external technological and social developments. Instead of a dialectical relation between subject and object, a one-way causal process is suggested, in which the individual is further reified and adopts a passive stance to the external world. As a consequence, a seemingly obvious point that is overlooked by Adorno`s analysis, is the active role played by the subject in the construction of reality, which is not only exemplified as adaption and docility to reified reality, but also, at times, takes unexpected and unpredictable forms - for example, as opposition and resistance against alienation.

On the other hand, and by unravelling the political implications of his theory of reification, Castoriadis underscored the active individual and collective reaction against this social process of mechanization, at times explicitly organised via unions, strikes and revolutions and at times expressed as every day struggles in the workplace taking the form and functioning as 'invisible struggle'. (Castoriadis 1988a:183) Beneath the image of reification as frozen reality and capitalism`s continuous endeavour to dehumanize people, Castoriadis sees, in a way parallel to Adorno's 'social pathogenesis of schizophrenia' or 'psychotic character' (Adorno 2005: 230, 231), the social construction of a 'neurotic individual' (Castoriadis 1988b: 259) and the fundamental contradiction of 
capitalism. This inherent contradiction of capitalism is encapsulated in the tension and conflict between direction and execution within the sphere of production, which seems to necessitate, in a rather schizophrenic and contradictory manner, the realization, concurrently, of the participation and exclusion of the workers in the production process. This contradiction constitutes the vital source that generates the permanent crisis of capitalist society. Given this line of analysis and under the influence of Lukas's theoretical elaborations and echoing Weber's ideas, Castoriadis conceived of this process of dehumanisation and depersonalisation as a generalised reification that penetrates not only individuals but also social institutions, as well as the political and cultural domain. The crisis, thus, becomes all-embracing, as reification extends from the sphere of production to the most important facets of contemporary societies. The deployment of reification penetrates all aspects of social reality, which is then rendered objectifying for the subject. Capitalism's internal contradiction is extended to cover the totality of social relations covering and pervading every aspect of social reality.

As does Lukács, however, Castoriadis equates reification with both alienation and fetishism. The analysis of reification appears to conflate the two other concepts to the point where they are used interchangeably. In Castoriadis`s analysis of the crisis of capitalism, the three terms are fused and in most cases connote the process of thingification, objectification and dehumanization. Reification entails the separation between subject and object, between capital and labour, whose relation is seen as being an external one. Capital is perceived not as social relation, as an internal and antagonistic relation between capital and labour. Capital is reified as an independent entity and the insubordinate power of labour as internal contradiction within capital is not taken into consideration. In this respect, capital is understood as a thing externally opposed to labour. It attacks labour from outside, as a discrete economic mechanism that attempts to subjugate and depersonalise workers in the production process. This prompts the reaction of the working class, which opposes capital's aggressive policies. As Castoriadis argued 'the system ... necessarily engenders opposition, a struggle against it by those upon whom it seeks to impose it'. (Castoriadis 1988c: 93) Given this line of analysis, capital is the driving force, which always takes the initiative, makes its own decisions and thus 
provokes the militancy and class struggle of the labour movement, which in turn generate the crises of the capitalist system: 'the capitalist structure of society consists of organizing people's lives from the outside... and creates a perpetually renewed crisis in every sphere of human activity'. (Castoriadis 1988c: 93, 92) Capital shapes and structures our social doing from the outside and from a similar viewpoint, that is, from the outside, the revolted subjectivity fights against capital`s domination. In this kind of case, for Castoriadis, class relations are apprehended as relations of domination rather than exploitation. As a result, the limits and contradictions of capital are not grounded in the insubordinate power of labour as internal contradiction within capital, but are placed in the conflict between directors and executants, between participation and exclusion. Those latter contradictions constitute both the driving force and at the same time act as a brake on the unfettered development of capitalism owing to the instability and crises they bring about.

\section{Crisis, Autonomy and Unlimited Expansion of Rational Mastery}

Castoriadis broaches the theme of reification again in the third chapter of his The Imaginary Institution of Society (1975). Once again, he does not make a distinction between reification, alienation and fetishism and he appears to ignore or take no notice of Marx`s elaboration of the concept of fetishism put forward in his critique of 'Trinity Formula' in the third volume of Capital. Castoriadis reiterates his view that the notion of reification denotes the dehumanization of the members of the exploited and dominated classes. Yet, he supplies an erroneous treatment of the reification as a transhistorical category, as he applies the notion equally to both workers in capitalism and slaves living in antiquity. Castoriadis develops a rather confusing critique of Marx`s views, by suggesting that Marx considers workers`s status under capitalism to be sufficiently low as to render them merchandises and by arguing, against Marx, that in the phenomenon of reification the worker is reduced neither to a thing nor to a mere commodity. Castoriadis tends to forget the fundamental distinction made by Marx between labour and labour power. As Fine forcefully reminds us, 'the juridic significance of Marx`s discovery that 
workers sell their labour-power and not themselves or their labour was this: it enabled him to see that workers [...] remain at all times owners of a commodity that is, labour power. They are guardians of a commodity rather than being themselves commodities; they are in this sense free workers rather than slaves'. (Fine 1984: 119) Conversely, Castoriadis stresses the point made in his earlier texts pertaining to the "relativity of the concept of reification', by pointing out that 'it is the struggle of slaves or of workers which questions reification and relativizes it as a category and as a reality'. (Castoriadis 2005: 391) He continues to grasp reification as a dynamic concept and underscores the crucial role of the class struggle. He also persists in comprehending capital and the process of reification as an analysis of domination. This approach was a corollary of his gradual break with Marxism and mirrors his critique of the Marxian theorizing. His critique of what he considered to be Marx`s rationalism, positivism and economism went parallel with his decision to move beyond 'beyond "class thinking" '. (Castoriadis 1992: 224) Concurrently, the focal point of his theory shifts to the unfolding of the notion of 'social imaginary significations'.

Castoriadis`s interpretation of the social character of the USSR or China best exemplifies the nub of his criticism of Marxism and his development of the concept of 'social imaginary significations'. His approach, articulated through Weberian lenses, was based on the assumption that the increasing rationalisation and bureaucratization of modern social and economic life cannot be explicated with an analysis of production and the economy. The increasing vital role played by institutions of state and bureaucracy and the occurrence of common sociocultural forms, such as the social imaginary significations, have led both western and east European regimes to converge. These developments gave rise to a new social system which Castoriadis names 'bureaucratic capitalism'. This novel social formation consists of two variants, that is, 'total bureaucratic capitalism' in the USSR and the 'fragmented bureaucratic capitalism' in western societies. What both types of bureaucratic capitalism have in common is that they belong to the same socialhistorical universe. Their distinctive characteristic is not that they are ruled by capital, but that they are dominated and penetrated by similar 'social imaginary significations', such as the central role of economy, the emphasis placed on technology and organization in 
the production process or the obsession with development, progress and quantitative growth. The intersection and connection of all these social imaginary significations is realized through the imaginary signification of 'rational' mastery which subsists both in Marxian problematic and the capitalist universe. The specificity of these significations lies in the fact that they are 'relatively independent of the signifiers that carry them and that they play a role in the choice and in the organization of these signifiers. These significations can correspond to the perceived, to the rational or to the imaginary'. (Castoriadis 2005: 139) Through this new prism, reification is seen as an operative signification' and defined as an 'imaginary meaning'. (Castoriadis 2005: 140) Castoriadis views reification as profoundly determined by institutions, under which he also subsumes the production relations. Equally, reification is operative in its function and it bears considerable social and historical implications as it, in turn, coordinates human action and manages social relations. What Marx failed to grasp, according to Castoriadis, is that in each society there is a central imaginary, which is not only indissoluble from the constitution of actual social contradictions, but is also 'at the root of alienation as well as of creation in history'. (Castoriadis 2005: 133)

In one of Castoriadis`s first attempts to explicate and elucidate the concept of imaginary, he turns to Marx, and quotes as follows from the section on 'fetishism' in Capital, Vol I:

'...a definite social relation between men...assumes, in their eyes, the fantastic form of a relation between things. In order, therefore, to find an analogy, we must have recourse to the mist-enveloped regions of the religious world. In that world the productions of the human brain appear as independent beings endowed with life, and entering into relation both with one another and the human race. So it is in the world of commodities with the products of men's hands. This I call the Fetishism which attaches itself to the products of labour, so soon as they are produced as commodities...' (Castoriadis 2005: 389)

Discussing the aforementioned quote, Castoriadis remarks that Marx 'obviously went beyond purely economic view and recognized the role of the imaginary'. (Castoriadis 2005: 132) This assumption enabled him to criticize Marx`s for assigning a limited significance to the social function of the imaginary, which derived from the insufficient development of technology. In other words, imaginary formations emanated from 
society's inability to resolve its own contradictions. Yet, at this point, Castoriadis appears to perform an absolute misreading of Marx`s words and intentions. Evidently, if one conceives of Marx`s analysis of fetishism as his effort to move beyond economic interpretations and explicate the origins of society's imaginary constructions, such as God and religion, then Castoriadis rightly criticizes him for an inadequate and restricted undertaking. Taking them at face value, Marx`s observations pertaining the genesis and reproduction of religious consciousness has little merit, and one could argue that they are rather naïve, over-simplistic, problematic and uncritical.

In contradistinction to Castoriadis's approach, however, one could argue that Marx employs the example of the religious world as an 'analogy' in order to explain and criticize the 'doubling' of the world, which leads to a double life, a life in heaven (of religion, philosophy, law, state, economic forms and abstractions) and a life on earth (society, social relations, human practice). The key issue, then, is not to define, explain God or the role of the imaginary, but to criticize this 'twofold existence', this 'enchanted, perverted, topsy-turvy world' (Marx 1984: 830) so as to demystify and decipher it on a human basis. For Marx, there is only one world created by human social practice. Marx did seek to go beyond 'purely economic view', as Castoriadis claims, aiming to replace or complement his analysis with the investigation of other ideological, psychological or cultural forms. Marx sought to provide a critique of political economy, which, amongst other things, amounts primarily to a critique of fetishism. In capitalism, according to Marx, human beings are enslaved in their own creation. They are enslaved and get lost in what they have created and produced. Their life-practice takes the shape of various perverted forms. Human practice, as the essence of things, is the basis of social constitution, but it is concealed in these inverted and distorted forms, and it needs to be de-mystified. The creators are dominated by their creation and governed by abstractions, by abstract economic forces and laws. Human social relations exist in the forms of money, state, capital or law; they are constitutive of these forms and yet they look as if they are ruled by them. It seems that poverty, inequalities and misery derive from something beyond human control. It occurs that we are governed by coins, economic products and abstract financial markets. Those who constitute appear suddenly as 
derivatives of an inverted world. Marx`s wants to reveal the content, the essence, the human relations which are hidden in this 'topsy-turvy world'. He criticized economic categories with the purpose of deciphering their social constitution. Marx`s attempt rests on the comprehension of social practice that creates the abstract and imaginary worlds, and at the same time, on the understanding of how the phantasmagoria of social relations between things constitutes human social relations. As Tomba has vehemently point out,

The phantasmagoria constitutes the negative of modern rationality: not its negation, but its trace. The Cartesian project of the foundation of rationality on the certainty of the ego cogito is placed in check. In the phantasmagoria, the senses 'deceive us' in an objective way; equally objectively, 'waking can never be distinguished from sleep'. Marx emphasizes how the effect of fetishism is not simply illusory, but objective. The phantasmagoria puts us in an inverted world of spells and spectres. Marx does not propose an Enlightenment-style critique. He does not intend to deny the existence of monsters, but to demonstrate how real monsters really produce a monstrous imaginary. Hence, the project of Capital announces in the 'Preface' of 1867: "we have to remove the "magic cap" that we draw down over our eyes and ears as a make-believe that there are no monsters'. (Tomba 2013: 94-5)

Marx`s critique aimed to demonstrate the human content of these monstrous imaginaries, to decipher them on a human basis. He envisages a society of the free and equals, in which rational organization and collective self-management will make economic laws and abstractions that now come across as being independent and inexorable, disappear. Marx`s social critique, then, asks to bring to the fore the social constitution of the inverted world of capitalist forms. As he put it, "all emancipation is reduction of the human world and of relations to man himself'. (Marx, 1992: 234) On the contrary, in Castoriadis's approach the real, the social constitution of the world is not questioned, but it is doubled. In one of the preparatory drafts, which was written before the publication of The Imaginary Institution of Society, Castoriadis attempted to elucidate the meaning he attached to the concept of the imaginary:

We can grasp the imaginary as soon as we ask a basic question: what are the most general conditions for the existence of an individual subject or a collectivity of subjects? These conditions can be summed up in two points: there is a given reality that is a resistant ground $(\mathrm{sol})$, coherent and inexhaustible; and a given other of reality, not a (real) negation of the real, but an a-reality. The latter springs from and is supported by the essential characteristic of subjects, that is their ability to ignore the real, to detach themselves from it, to put it at a 
distance; and thus to take a view that differs from the seemingly straightforward one, to add to reality an unreal extension, to think of something else, to represent and do what is not given, and to make the possible exist. This essential characteristic, constitutive of human existence, is what I call the imaginary (or the imagination, when the emphasis is on the corresponding activity). (Castoriadis 2015: 60)

For Castoriadis, society is split into two parts, two worlds: a) the given reality and b) an a-reality. The latter, which Castoriadis calls 'imaginary' or 'imagination', exists independently of the human subjects and although it emanates from them, it constitutes their social existence and the modes of their subsistence. Whereas Marx, as Tomba put it, 'did not move towards the heavens of abstraction, but towards the materiality of acting and suffering bodies', (Tomba 2013: 92) Castoriadis turned to spiritualism, by seeing heaven instead of earth. The changing complex of social relationships torn by class antagonisms are replaced with 'individual subjects or a collectivity of subjects' and social imaginary significations become the motive forces of history. Society remains divided not into antagonistic social classes, but is split between reality and a-reality, real life and the imagination. Castoriadis's individual subjects are detached from the relations of production. His break with Marxism was rooted in his rejection of economic reductionism. Now he too reduces the human relations and the genesis of social phenomena to one essential function: that of the imaginary. The contradictory constitution of social relations is overlooked and the connection with the conditions of social reproduction is broken. Departing from a concrete analysis of the contradictions rooted in production and social relations, Castoriadis replaces actual history, conflicts and struggles with the history of social imaginary significations. This time the antagonism between labour and capital or between directors and executants is restored and substantiated into the struggle between autonomy and capitalist rationalization.

Castoriadis unfolds his own scheme of explication the evolution of modernity as well as the contradictions and the roots of capitalist crises. The alternative he puts forward is the periodization of modernity, and mainly the Western European history, which is based on the specificity of the imaginary signification of 'autonomy', its emergence and eclipse, as well as its conflict with a new social imaginary signification, that is, the unlimited 
expansion of 'rational mastery'. On the basis of these two central social imaginaries, which appear to come into conflict as two externally constituted entities of a heavenly world, Castoriadis constructed a course of events or rather a canonization of history. Thus, he divided European history into fundamentally three distinct periods, which are derivative of the two social imaginaries: a) The first period is extended from the twelfth to the early eighteenth century and is characterized by the constitution of the West and the re-emergence (after its genesis in the ancient Greek democracy) of the idea of autonomy. b) The second phase, from 1800 to 1950, witnessed the emergence and creation of capitalism, which 'embodies a new social imaginary signification: the unlimited expansion of "rational mastery". (Castoriadis 1997: 36) Throughout this historical stage, the conflict between the two imaginary significations, that is to say, the struggle between autonomy and unlimited expansion of "rational mastery", defined the character of the socio-economic reality and constituted the driving force of the extraordinary growth and advance of Western societies. (Castoriadis 1997: 39) c) Finally, the third period, which starts from 1950, is the epoch of a generalized conformism. The social and political conflicts disappeared and more precisely, after the 'semifailures' of the `60`s social movements 'the project of autonomy seems totally eclipsed'. (Castoriadis 1997: 39) According to Castoriadis`s periodization of modernity, then, history is systematized and structured in line with the adventures of the project of autonomy, its successive emergence and eclipse, and its antagonism with the imaginary of "rational mastery'. Modernity is subjected to a unified approach and is instituted on a dualistic scheme, which tries to comprehend the specificity of Western European history from the twelfth century to the present day and its own particular crises. On this criterion, Castoriadis opined that, from 1950 onwards, a date which Castoriadis himself admits is 'evidently arbitrary' (Castoriadis 2003a: 83), the Western world entered into a period of permanent crisis. What is particularly noteworthy is his viewing of the profound crisis of modern capitalist societies as an on-going and long-lasting social phenomenon, which has begun to express itself in new forms of barbarism. Hence, it has taken on all the characteristics of decline and decadence. Generalized conformism is increasingly being transformed into generalised decomposition. 


\section{From Crisis to Decline to Insignificancy}

The central importance that Castoriadis's interpretation of the phenomenon of crisis holds in his theoretical production is also signaled in the last stage of his intellectual itinerary. Lukács, in one of his last interviews in 1970, maintained with reference to the crisis of capitalism that the 'whole system is facing the initial stages of an extraordinarily profound crisis' and made it explicit that 'we are at the threshold of a world crisis. The threshold can, of course, mean 50 years'. (Lukács 1970: 44) Castoriadis, on the other hand, insisted in his argument that since 1950 the 'Western World has entered into crisis, and this crisis consists precisely in this, that the West ceases to call itself truly into question'. (Castoriadis 2003a: 83) Castoriadis's proposition posits a strong connection between crisis, critique and the inability to offer a radical alternative to crisis. From his perspective 'the crisis of criticism is only one of the manifestations of the general and deep-seated crisis of society'. (Castoriadis 2003b: 130) The regression even of the traditional functions of critique, as it was used to manifest itself in the press or academia, has undermined the foundations of the Western liberal model. This lack of substantial critique, self-reflection and self-criticism has extended generalized conformism, depoliticization and apathy to cover the totality of social life in modern societies. Immaturity, in Kant`s understanding of the term, has become a generalised phenomenon penetrating and prevailing even in the traditional opposites of the capitalist system, that is, the Left and the organized labour movement. The dynamic elements that critique as critical-practical activity used to contribute for the rejuvenation of the static conditions of society have been downplayed and nearly diminished. This loss of the critical function, of negative and destructive critique, has produced, as Adorno put it, the 'symptoms of paralysis which precede the ruin of the static order'. (Adorno 1961: 36) Castoriadis associates these symptoms of decadence with the mystification of the alternatives and the role played by the private mass media and 'the vacuum industry' (Castoriadis 2003c: 213). He interprets these signs of decay as a result of society's failure to produce an alternative to capitalism project, a new radical undertaking that puts forward the direction toward which we are heading. In this sense, modern society is in crisis, according to Castoriadis, because 'it is not capable of engendering another way for people to be together'. (Castoriadis 2003d: 224) 
In his later theoretical development, Castoriadis placed much more emphasis on the social, human, political and cultural character of the crisis, building upon ideas he had first sketched out in his earlier writings. In his article Recommencing the Revolution, for instance, he argued that the analyses of the crisis of capitalist production in conjunction with the crisis of the political organizations and institutions 'must be complemented by an analysis of the crisis in values and in social life as such, und ultimately by an analysis of the crisis in the very personality of modern man'. (Castoriadis 1993b: 40) Following this line of inquiry, he views the eruption of economic and financial crises as merely symptoms of a much deeper and profound crisis, which is related to the process of a generalised decomposition and decline of capitalist societies. This decay is evident as a crisis of social and human values or as a crisis in the meaning of life and of human motives, which have led to the emptiness and poverty of everyday life. Castoriadis attributes the pervasive corrosion of values and morals, as well as the dislocation of human social relations and collective ways of life, to a 'void of signification'. In other words, crisis becomes visible as a crisis of the significations and meanings that used to hold modern societies together. People retreated into their private sphere, feeling powerless to collectively control, organize and direct their lives. The abstract forces of the financial market and the rule of money prevail and their function takes the form of inexorable laws, which stand above society and becomes uncontrollable. The crisis of socialization and the disappearance of responsibility and liability are coupled with prevailing values, which are those of market-driven neo-liberal ideology: individualism, competition, efficiency, flexibility, consumption and money. This process addresses significant issues concerning the meaning of human existence and creates a new type of human, who has great difficulties in filling the content of their life with positive motivations. As Castoriadis emphatically put it, referring to the modern individual, 'he runs, he jogs, he shops in supermarkets, he goes channel surfing', but 'nothing he does [...] has the slightest meaning'. (Castoriadis 2003d: 228)

Social disarticulation finds its expression in the crisis of culture and the disintegration of modern individual. From Castoriadis`s vantage point, the rising tide of insignificancy, which has shaped the character of modern western societies, has led to the emergence of 
a new 'anthropological type'. This new human type contradicts the Protestant work ethic and its call to self-discipline, as well as the traditional anthropological types, which constitute an indispensable element for the smooth operation and reproduction of capitalist society: the 'Schumpeter-style entrepreneur' as well as 'incorruptible judges, honest Weberian-style civil servants, teachers devoted to their vocation, workers with at least a minimum of conscientiousness about their work, and so on'. (Castoriadis 2003a: 88) Castoriadis has categorically correlated the 'anthropological type' or the 'anthropological question' with the social conditions they have sprung from. Nonetheless, the issue at stake here is that due to his reference to cultural elements and the impact of the social imaginaries, his analysis to be perceived as a critique of the cultural underpinning of modern societies that leaves untouched - and hypostasizes — the capitalist social relations as something natural and eternal. On this, Habermas (Habermas 1996: 42) reminds us that neoconservatism contends that modernist culture has come to erode the norms and values of the Protestant ethic, by instilling in modern individuals principles and doctrines that are incompatible with the demands of professional life in modern societies. Habermas gives the example here of Daniel Bell, who sought to account for the critical split between culture and society in advanced Western societies, calling for a return to traditional and religious values in order for the decay of the individual to be transcended.

From a more radical vantage point, Adorno made a significant point, which is directly opposed to conservative analyses. He wrote, 'reactionary criticism often enough attains insight into the decay of individuality and the crisis of society, but places the ontological responsibility for this on the individual as such, as something discrete and internal: for this reason the accusation of shallowness, lack of faith and substance, is the last word it has to say, and return to the past its solace'. (Adorno 2005: 148) Seen through Adorno`s prism, then, Castoriadis`s views concerning the rising tide of insignificancy, emptiness and superficiality must not been grasped as an ahistorical critical explanation of late modernity. If 'insignificancy' is detached from contradictory and antagonistic social relations, then it runs the risk of becoming fetishized as an invariant catchwork and a new embellishment of capitalism`s decline. In this sense, 'insignificancy' fails to reflect 
capitalism`s transition away from its classical liberal classical form, which Castoriadis`s immanent critique attempted to demonstrate. It acts as an abstract form, which pictures one aspect of the decay, but it is unable to explore its origins. Overestimating the importance of the concept of 'insignificancy' and applying it mechanistically entails 'accept[ing] symptoms uncritically'. (Adorno 1967b: 47)

In an exchange with Christopher Lasch concerning 'The Culture of Narcissism', Castoriadis revisited the same claim - that since the end of the 1950s people had begun retreating into their private sphere. Life came to connote a struggle for survival. The expression 'one day at a time' captures not only the lack of an individual and social project, but also signifies that the time horizon has been transformed into a private one: 'Nobody participates in a public time horizon'. (Castoriadis 2011b: 69) This has been also made evident at the political level. Insignificancy, cynicism, social and political apathy, corruption and bureaucracy were coupled with the people's acceptance of the movement towards privatization. The division between Left and Right has been blurred and politics has become 'practically indistinguishable from any other form of advertising or sale of products'. (Castoriadis 1993c: 111) 'These are absurd times' Castoriadis comments and concludes: 'We're living in bad times, that's all'. (Castoriadis 2010: 131, 134) According to Agnoli, 'the true characterization of 'liberal democracy' is ... constitutional oligarchy'. (Agnoli 2000: 201) Castoriadis resorts to a similar observation. He considers modern Western neo-liberal societies as 'Liberal Oligarchies' (Castoriadis 2003a: 78), which especially after the collapse of the left-ideologies, are experiencing an 'ideological aberration', which 'is itself an important sign of the crisis. There is no new subversive or revolutionary discourse, but there is no conservative discourse either'. (Castoriadis 2003d: 225)

However important, although under-acknowledged, Castoriadis`s study of the crises and contradictions of modern capitalist societies is, he exposes himself to the same charge he makes against orthodox Marxism. At times, he examines the economic, social, political, ideological and cultural dimensions of crisis as isolated phenomena. In his attempt to depart his approach from the economism of the Marxist perspective, he neglects the fact 
that all these expressions of the crisis must be examined as a whole, as different aspects of capitalist social relations. Class and productive relations, the relation between capital and labour, express themselves through various forms and appear as discrete symptomsphenomena of the crisis. It is hard to avoid a reductionist approach, if these different manifestations of the crisis are examined independently and in isolation from one another, as seen in some of Castoriadis's writings. Thus, these phenomena constitute a contradictory unity, run into one another and meet as inter-connected fragments of one unified process, may it be crisis, decline or barbarism. That said, in his analysis of crisis, Castoriadis does not exclude the historical possibility of a regression to barbarism. Nor loses sights he of the possibility of human emancipation through the unfolding of the project of social autonomy. As Curtis vehemently underscores, the theme 'Socialism or Barbarism' constitutes an 'important yet neglected aspect' of Castoriadis`s work. Unfortunately, however, 'critics have neglected this alternative, and its neglect has impaired the understanding of the meaning, import and direction of his work'. (Curtis 1989: 293) What is distinctive in Castoriadis`s writing, as Curtis has argued, pertains to his contention that barbarism is viewed 'as a present negativity tied to the prospects of socialism. Whereas Trotsky pushed the prospect of barbarism into the future, making it a soon-to-be-present negativity (or a possibility whose time would pass), Castoriadis insisted that "barbarism is not a historical stage suddenly appearing after the capitalist system has reached its point of impasse. It already makes its appearance in decaying capitalism too." ' (Curtis 1989: 300) Castoriadis`s discussion of the dialectics between barbarism and socialism is important for at least two reasons. The ongoing crisis of capitalist societies and its final outcome is ambivalent, as much as the man-made historical possibilities are open and unpredictable on both sides. Finally, the option of slipping into new forms of barbarism coexists with the prospect of human emancipation. Adorno makes this point well: 'In a world of brutal and oppressed life, decadence becomes the refuge of a potentially better life... What can oppose the decline of the west is not a resurrected culture but the utopia that is silently contained in the image of its decline'. (Adorno 1967a: 72) 


\section{NOTES}

${ }^{1}$ As Castoriadis put it: 'To work and to struggle is the only thing we can do to keep a project of emancipation, of liberation, alive'. (Castoriadis 1995: 33) Also see in one of his interviews in 1991 and in his answer to the question of what the role of the intellectual should be, Castoriadis clarified his approach, with eloquent precision, thus: 'Uncompromising criticism of existing realities and elucidation of the possibilities for transforming them'. (Castoriadis, 2011a: 108)

2 Despite contrary interpretations, Castoriadis summarizes his relationship with Marx succinctly in the following: 'Looking back, my fundamental political orientation is without doubt rooted in the work and engagement of Marx' [...] 'The concern to combine understanding with a project of change I have learned from Marx, or invented, I don't know which. In this sense there is a bond between Marx and me. I privilege Marx over the other great thinkers because he tries again to be a philosophical citizen and citizenphilosopher'. (Castoriadis 1995: 31)

\section{BIBLIOGRAPHY}

Adorno, T. (1961) “"Static" and "Dynamic" as sociological Categories', Diogenes, 9: 2849.

Adorno, T. (1967a) 'Spengler After the Decline', in Adorno, T. (1967) Prisms (Cambridge, Massachusetts: The MIT Press).

Adorno, T. (1967b) 'The Sociology of Knowledge and its Consciousness', in Adorno, T. (1967) Prisms (Cambridge, Massachusetts: The MIT Press).

Adorno, T. (2003) Negative Dialectics (London: Continuum).

Adorno, T. (2005) Minima Moralia: Reflections on a Damaged Life (London: Verso)

Adorno, T. and Horkheimer, M. (2011) Towards A New Manifesto (London: Verso)

Agnoli,J. (2000) 'The Market, the State, and the End of History', in Bonefeld, W. and Psychopedis, K. (ed.) The Politics of Change: Globalization, Ideology and Critique (Basingstoke: Palgrave). 
Castoriadis, C. (1988a) 'On the Content of Socialism, III' in D. A. Curtis (ed.) Cornelius Castoriadis, Political and Social Writings, Vol. 2, 1955-1960: From the Workers' Struggle Against Bureaucracy to Revolution in the Age of Modern Capitalism (Minneapolis: University of Minnesota Press).

Castoriadis, C. (1988b) 'Modern Capitalism and Revolution' in D. A. Curtis (ed.) Cornelius Castoriadis: Political and Social Writings, Vol. 2, 1955-1960: From the Workers`Struggle Against Bureaucracy to Revolution in the Age of Modern Capitalism (Minneapolis: University of Minnesota Press).

Castoriadis, C. (1988c) 'On the Content of Socialism, II', in D. A. Curtis (ed.) Cornelius Castoriadis: Political and Social Writings, Vol. 2, 1955-1960: From the Workers' Struggle Against Bureaucracy to Revolution in the Age of Modern Capitalism (Minneapolis: University of Minnesota Press).

Castoriadis, C. (1992) 'The Crisis of Marxism, The Crisis of Politics', Dissent, Spring: 221-225.

Castoriadis, C. (1993a) 'The Diversionists' in D. A. Curtis (ed.) Cornelius Castoriadis: Political and Social Writings, Vol. 3, 1961-1979: Recommmencing the Revolution: From Socialism to Autonomous Society (Minneapolis: University of Minnesota Press).

Castoriadis, C. (1993b) 'Recommencing the Revolution' in D. A. Curtis (ed.) Cornelius Castoriadis, Political and Social Writings, Vol. 3, 1961-1979: Recommencing the Revolution: From Socialism to Autonomous Society (Minneapolis: University of Minnesota Press).

Castoriadis, C. (1993c) 'The Crisis of Modern Society' in D. A. Curtis (ed.) Cornelius Castoriadis, Political and Social Writings, Vol. 3, 1961-1979: Recommencing the Revolution: From Socialism to Autonomous Society (Minneapolis: University of Minnesota Press).

Castoriadis, C. (1995) 'Cornelius Castoriadis' in Rötzer, F. Conversations with French philosophers (New Jersey: Humanities Press).

Castoriadis, C. (1997) 'The Retreat from Autonomy: Postmodernism as Generalized Conformism' in D. A. Curtis (ed.) World in Fragments (Stanford: Stanford University Press). 
Castoriadis, C. (2003a) 'The Dilapidation of the West', in C. Castoriadis The Rising Tide of Insignificancy (The Big Sleep). Translated from the French and edited anonymously as a public service. Available at http://www.costis.org/x/castoriadis/Castoriadisrising tide.pdf

Castoriadis, C. (2003b) 'The Rising Tide of Insignificancy' in C. Castoriadis The Rising Tide of Insignificancy (The Big Sleep).

Castoriadis, C. (2003c) 'The Vacuum Industry' in C. Castoriadis The Rising Tide of Insignificancy (The Big Sleep).

Castoriadis, C. (2003d) 'The Crisis of the Identification Process' in C. Castoriadis, The Rising Tide of Insignificancy (The Big Sleep).

Castoriadis, C. (2005) The Imaginary Institution of Society (Cambridge: Polity Press).

Castoriadis, C. (2010) 'These are Bad Times' in Escobar, E. Gondicas, M. and Vernay, P. (ed.) A Society Adrift: Interviews and Debates, 1974-1997 (New York: Fordham University Press).

Castoriadis, C. (2011a) 'The Crisis of the Imaginary?' in C. Castoriadis Postscript on Insignificancy. Translated from the French and edited anonymously as a public service. Available at http://www.notbored.org/PSRTI.pdf

Castoriadis, C. and Lasch, C. (2011b) 'Beating the retreat into Private Life' in C. Castoriadis Postscript on Insignificancy.

Castoriadis, C. (2015) 'The Imaginary as Such', Social Imaginaries, Vol. 1, Issue 1: 5969.

Curtis, D. A. (1989) 'Socialism or Barbarism: The alternative presented in the work of Cornelius Castoriadis', in G .Busino (ed.) Autonomie et autotransformation de la société. La philosophie militante de Cornelius Castoriadis (Geneva : Droz).

Fine, B. (1984) Democracy and the Rule of Law: Marx`s Critique of the Legal Form (New Jersey: The Blackburn Press) 
Habermas, J. (1996) 'Modernity: An Unfinished Project', in d'Entrèves, M.P. and Benhabib, S. (ed.) Habermas and the Unfinished Project of Modernity (Cambridge: Polity Press).

Horkheimer, H. (1972) 'Traditional and Critical Theory', in Horkheimer, M Critical Theory: Selected Essays (New York: Herder and Herder).

Kosik, K. (1976) Dialectics of the Concrete (Boston: D. Reidel Publishing Company).

Lukács, G. (1970) ‘The Twin Crises’ New Left Review 60: 36-47.

Lukács, G. (1971) History and Class Consciousness (London: Merlin Press).

Marx, K. (1984) Capital, Volume III (London: Lawrence and Wishart).

Marx, K. (1991) 'Theses on Feuerbach', in Marx, K. and Engels, F. Selected Works (London: Lawrence and Wishart).

Marx, K. (1992) On the Jewish Question, in Marx, K. Early Writings (Harmondsworth: Penguin)

Tomba, M. (2013) Marx`s Temporalities (Chicago, IL: Haymarket Books) 